\title{
PSALM CX.
}

IN dealing with a difficult Psalm, like the present, the historical method is the only fair and profitable method of study. We must put out of our mind for a while all preconceived ideas. We must read it as though we read it now for the first time. We must try to find out what it meant to the men to whom it was first spoken -how it was to them a Divine message. But, when we have done this, we must remember that no Word of God exhausts its meaning upon one age : we are therefore not merely justified in asking, but we are obliged to ask, What were the thoughts and traditions which have gathered round this Psalm in later times and have so transmitted God's message to the ages? For I suppose we shall most of us admit that the same Spirit which moved holy men to write has also, in every age, moved holy men to read in that writing that portion of an infinite truth which was intended for their age. In other words, tradition must itself be reckoned as a factor in Inspiration.

And now let us become merely critics to determine

\section{The Meaning of the Psalm and the Date of its Composition.}

The Title in itself proves nothing: since $(a)$ no title forms part of the text, and (b) many Psalms are, by their titles, ascribed to David which could not possibly have been written by him.

Again, it is recognized by scholars that the Psalms as we have them now grew out of three collections, made at widely different times, the third and last collection (Ps. $\mathrm{xc}-\mathrm{cl}$ ) being placed by Kautzsch as late as B. C. 14 r.

Of course it may be argued that a late collection of hymns may contain some of great antiquity, but if this collection was made 800 years after David's death we must, at least, admit that the evidence of his authorship, which rests only upon the title, is slight indeed. 
Let us now turn to the Psalm itself and endeavour to determine, from internal evidence, the age to which it belongs.

Ps. CX.

\section{[Part I. The Coming One is a King.]}

1. Thus saith YнVH to ' my lord ' ':-

'SIT THOU AT MY RIGHT HAND

The

Divine

TILL I MAKE THY FOES A FOOTSTOOL FOR THY FEET.'

Word.

2. The rod of thy strength shall YHVH send forth out of Zion. The

Rule thou in the midst of thy foes.

3. Thy people offer ${ }^{2}$ themselves willingly in the day of thy mustering-host.

Psalmist

meditates

on its

fulfilment

(cf. $v v$

In the beauty ${ }^{3}$ of holiness, from the womb of dawn, thou $5^{-7}$ ).

hast the dew of thy youth ${ }^{4}$.

[Part II. The Coming One is a Priest.]

4. YHVH hath sworn-and He does not repent-

'THOU ART A PRIEST FOR EVER,

AFTER THE ORDER OF MELCHIZEDEK.'

5. Adonai ${ }^{5}$, at Thy right hand, hath smitten kings, in the day The of his wrath :

The

Divine

Word.

6. He judges among the heathen, it [i.e. the battle-field] is filled with dead;

He hath smitten the head, over a wide land.

on its

fulfilment

(cf. $v 2$.

2, 3).

7. He will drink of the brook in the way, therefore he will lift up his head.

\section{NOTES.}

v. 3. The two readings, 'in the beauties of holiness,' 'in the mountains of holiness,' have about equal weight. If we adopt the former we have an expression which nowhere else occurs, and which, judging from the analogy of I Chron. xvi 20 ; Ps. xxix 2, xcvi 9, would rather denote holy sanctuaries than holy garments: whereas if (with Midrash Rabbah, Sym. Jer., \&c.) we adopt the latter we have an expression which at least in the singular ('holy mountain') is very common, and which occurs in the plural in Ps. lxxxv11 I. Zion is called God's holy mountain because it is an earthly counterpart of the holy mountain of Heaven (Ezek. xxvili i 4). The mountains, also, are more naturally coupled with the thought of
1 Adoni.
2 Cf. Jud. $v 2$.
- Only here and Eccl. xi $g$ f.
3 Or mountains, Sym. Jer.
I my lord, 25 v. 1. 
'dew' and of the 'dawn': thus we read of 'the dawn spread upon the mountains' (Joel ii 2), 'the dew of Hermon' (Ps. cxxxiii 3; cf. 2 Sam. i 2 I).

'The dew of thy youth.' Many modern commentators interpret 'thy youth' as 'thy young men,' i. e. 'thy youthful soldiery.' But the only other passages in which this word 'youth' occurs are in Eccles. xi 9, 10, where it is once translated 'youth' and once (perhaps better) 'childhood.' It is, then, evident that 'the dew of thy youth' implies a birth that is ever fresh, a constant renewal of youth (cf. Isa. xxvi r9). Just as the Morning-star is called 'the son of the dawn' (Isa. xiv 12) because it seems each morning to be born anew, so, too, of the Hero of our Psalm, 'His going forth is prepared as the dawn' (Hos. vi 3 ); but though 'His goings forth have been from of old, from everlasting' (Mic. v 2), yet his youth is ever new.

This interpretation will also throw some light upon the last line of the Psalm, which holds the same relation to Part II that the present line does to Part I.

v. 5. 'Adonai, at Thy right hand,' \&c. Adonai is pointed here as if it were the name of God, and is usually translated 'The Lord.' But it seems to me that the structure of the Psalm requires us to take it, as in $v . \mathrm{I}$, of the Messiah. And this for the following reasons :-

(a) In vv. 2, 3 the meditation is not upon the action of God, but upon the action of Messiah : we should therefore naturally expect that in the corresponding verses of Part II the action would also be that of the Messiah.

(b) In Part I Messiah is seated at God's right hand; it would therefore be strange, in Part II, to picture God at the right hand of the Messiah.

(c) Lastly, 'He will drink,' \&c. (v. 7), must refer to Messiah. Why then should not 'He judges,' \&c., 'He hath smitten,' \&c., also refer to Messiah?

v. 7. 'He will drink of the brook in the way . . ' This difficult line is supposed by many commentators to be a fragment; but, if we look at the structure of the Psalm, we see that it corresponds exactly with the last line of Part I. There Adonî, like a rising sun, on the 'holy mountains,' had a renewal of unending birth : here, like a setting sun, going down into the waters, he comes forth again with new vigour, rejolcing as a giant to run his course.

But the poet is still thinking of Gen. xiv or of the legend upon which that chapter was formed : just as Abraham pursued the four kings, so in a straight course (cf. Jer. xxxı 9), guided by God, Messiah pursues the powers of evil. The natural picture 1 , of course, of a warrior stooping to drınk and then continuing the pursuit. But the word 'drink' suggests a deeper meanıng; to 'drink the waters of Sihor' implies 
to be conformed to the customs of Egypt ; to 'drink the zeaters of the Rizer (i. e. Euphrates)' is to adopt the manners of Babylon (Jer. i1 I 8): therefore to drink of the brook in the God-guided Way suggests obedience to the God-guided life.

\section{On the Structure of the Psalm.}

We first observe that the Psalm falls into two natural parts, each commencing with a Divine Word, or Oracle. This Divine Word comes forth from YHVH and refers to a Being who is called Adonî, ' my lord,' in Part I, and Adonai, 'the lord,' in Part II'.

In Part I (vv. I-3) the Divine Word is, 'SIT THOU AT MY RIGHT HAND TILL I MAKE THY FOES A FOOTSTOOL FOR THY FEET.' i.e. Adonî is, by a Divine oath, constituted a King. The poet then $(v v .2,3)$ sees, as it were in vision, the nature of that Kingshipand it is unlike any other.

(a) He rules (v. 2) not with the strength of earth but with the strength of God.

(b) His subjects $(v \cdot 3)$ are rather priests than soldiers. Like Arthur's knights, the holiness of their King has made them willing volunteers to share his battles.

We feel at once that it is no common king that is here described, but that same Conqueror, with weapons not carnal, who has already been pictured in Ps. xlv.

In Part II (vv. 4-6) the Divine Word is,

' THOU ART A PRIEST FOR EVER

AFTER THE ORDER OF MELCHIZEDEK.'

i.e. This same holy King is also to combine the office of Priest. Clearly he could not have been of the race of Aaron, for, if so, there would have been no need for him to have been constituted Priest by a Divine oath. To make this still more clear we have the words, 'After the order of Melchizedek.' So then this PriestKing, even as he differs from other kings in the nature of his rule, differs also from other priests in the order of his priesthood. Next $(v v .5,6)$ the poet sees in vision the nature of that priesthood-and it, too, is unlike any other. For, as in Part I the King had ruled as a Priest, so here we see $(v v .5,6)$ a Priest conquering like a King.

\footnotetext{
1 The difference between Adoni and Adonai depends only upon the vowelpoints.
} 
We are now in a position to inquire, Was there any period in which the Messianic hope centred on a combination of the Kingship with the Priesthood? Certainly there was. Ezekiel had seen the fall of both priesthood and kingship. 'Remove the mitre, take off the crown . . . until he come whose right it is' (Ezek. xxi $26 \mathrm{f}$.). Zechariah saw, in the coming Messiah, the union of the two. To him Zerubbabel represented the House of David, while Joshua, the high priest, with equal dignity, represented the growing power of the priesthood; but when he pictures the coming Messiah (Tzemach, 'the Branch') both Zerubbabel and Joshua are merely types, the Messiah has more than combined the offices and dignity of both. This he sets forth in an acted parable (Zech. vi $9 \mathrm{ff}$.) :

'And the word of YHVH came unto me, saying, Take of them of the captivity, even of Heldai, of Tobijah, and of Jedaiah ; and come thou the same day, and go into the house of Josiah the son of Zephaniah, whither they are come from Babylon; yea, take (of them) silver and gold, and make a noble crown (lit. crowns) and set it (or them) upon the head of Joshua the son of Jehozadak, the high priest; and speak unto him, saying, Thus saith YHVH of hosts, Behold, the man whose name is Tzemach (the Branch or Outspring) he shall spring up out of his place, and he shall build the Temple of YHVH; even he shall build the Temple of YHVH; and he shall bear the glory (i.e. as King), and shall sit and rule upon his throne; and he shall be a priest upon his throne: and the counsel of peace shall be between them both' (i.e. the office of Messiah, both as priest and king, will be an office of Peace).

Now the name Tzemach, 'the Outspring,' is a most suggestive name for the Messiah, implying, as it does, not merely the dayspring [à $\nu a \tau, \lambda$, Jer. xxiii 5 ; $\mathbf{x x x i i i}$ I5 (Theod. and Sym.); Zech. iii 8 ; vi 12$]$, but also the effect of the dayspring upon creation by causing an 'outspring' from the ground [Isa. Ixi II]. The two thoughts are combined in Ps. lxxxv I2, "Truth shall spring out of the earth; and Righteousness shall look down from heaven.'

Jeremiah, alluding to this Spring-tide of Righteousness, says, 'In those days and at that time I will make to spring to David an Outspring of righteousness ... this is the name whereby it shall 
be called, унVн our Righteousness' (Jer. xxxiii I 5). In another passage ( $x$ xiii 5 ) he gives this same name to Tzemach himself. In Zechariah, as we have seen, ' the man whose name is Tzemach' is the Messiah, who combines in his own person all the highest thoughts of Kingship and of Priesthood.

Now it is evident that Tzemach has derived his attributes from natural religion, from what we may call the yearly parable of the Spring-tide. In other words Tzemach is, in the sphere of Revelation, what Tammuz is in the nature-religion of Babylonia and Palestine. The favourite name of Tammuz was Adoni, i.e. ' $M y$ Lord' (Ezek. viii 14, Heb. and Vulg.; cf. Jer. xxii I 8, Ah me Adón).

The fact that God's parable of Nature has been perverted into nature-worship is no argument against a right interpretation of that parable. I suggest therefore that a Psalmist who lived in the Persian period expressed under the name of Adonit that same Messianic hope which Zechariah had expressed under the kindred name of Tzemach. If the Psalm be read with this thought in mind some of the most difficult passages (e.g. vv. 3, 7) will gain a new light.

There is no period in the history of O.T. Revelation at which the Messianic hope approached so nearly to a Divine Theophany as in the Persian period.

If now we turn to Jewish tradition there is no question but that, in early times, Ps. cx was interpreted of the Messiah, though after the rise of Christianity it was, by the Rabbinic writers, applied to Abraham.

The meaning of Adonî in the first verse has always been a difficulty; the Zohar (quoted by Neale) says, 'The higher degree (YHVH) spake unto the lower (Adonî), Sit thou on My right hand' [Quoted as Zohar Gen.fol.15, col.139 ${ }^{1}$ ], thus giving a semi-divine meaning to Adont.

The Yalkut comments as follows :-

'In the time to come the Holy One, blessed be $\mathrm{He}$, is going to make $\mathrm{King}$ Messiah sit at $\mathrm{His}$ right hand and Abraham at $\mathrm{His}$ left. And the face of Abraham grows pale and he says, 'My son's son sits at the right hand and I at the left! Then the Holy One, blessed be He, appeases him and says, Thy son's son is at My right hand and I am at thy right hand.'

\footnotetext{
1 I have not been able to verify this reference.
} 
In the New Testament Christ appeals to this first verse with a view to show that the dignity of the Messiah would be greater than that of David. This may be said to have been His chief object, and, if our interpretation be correct, such a meaning was justified both by the intention of the Psalmist and by the voice of later tradition. The question of authorship is of minor importance.

If the words of Christ (Mk. xii $3^{6}$; Matt. xxii 44 ; Lk. xx 42) have been correctly reported, He claimed David himself as the author of the Psalm. This is, no doubt, a difficulty. But it is by difficulties, honestly faced, that God leads men to new truth. Most men now admit that there were things of which Christ was ignorant. (Mk. xiii $32:$ Lk. ii $40 \mathrm{ff} . \& \mathrm{c}$.)

But some will say, Limitation of knowledge is one thing, but mistake as to a matter of fact is quite another. If Christ could be mistaken in a matter of fact how can we look to Him as a sure Guide?

May not this difficulty be met by considering the nature of Inspiration? Holy men spake as they were moved by the Holy Ghost, and the more holy they were the more completely they reflected and transmitted the message of God. If it were possible to have conceived of one who should have been absolutely 'pure, undefiled, separate from sinners,' the Divine message through that man would have been unique so far as it concerned life and conduct : but there is no reason to suppose that it would have extended to facts of science or of history or of criticism.

In Heb. i I f. the message of God through Christ is compared, and at the same time contrasted, with that through the prophets: compared, as though it were the same in kind; contrasted, as being different in degree.

This being so, the absolute and unique authority of Christ, as the Way, the Truth, and the Life, is in no way affected even if it should prove that He was mistaken as to the authorship of a Psalm; but we positively assert that the inner meaning of the Psalm, as indicating the advent of a Priest-King of more than human power, was known and interpreted by Christ.

E. G. KING. 